\title{
Economic Impact of SUBICSHA on SHG Members of Kozhikode District
}

\author{
Abhinav, M.C.*, T. Paul Lazarus, Santha, A.M. and Brijit Joseph \\ Department of Agricultural Statistics, College of Agriculture Vellayani, Kerala Agriculture University, India \\ *Corresponding author: abhinavmc47@gmail.com
}

\begin{abstract}
The research entitled "Economic impact of SUBICSHA on SHG members of Kozhikode district" was conducted in Perambra block of Kozhikode district. SUBICSHA stands for Special project for Sustainable Business Development of Innovative Coconut Based Micro-Enterprises for Holistic Growth and Poverty Alleviation. It is an innovative women oriented, coconut based value added products venture and a women empowerment model. The objective of the study was to assess the economic impact of SUBICSHA on SHG members associated with SUBICSHA. Primary data were collected from 120 SHG members associated with SUBICSHA. Economic impact of SUBICSHA on SHG members was analysed based on before and after joining status using percentage analysis and paired t-test. It was found that the income levels, overall expenditure pattern, saving habit, borrowing power of SHG members have improved after joining SUBICSHA. SUBICSHA as a women empowerment and poverty alleviation programme was successfully implemented in Kozhikode district and SUBICSHA had significant positive economic impact on SHG members associated with it.
\end{abstract}

Keywords: SUBICSHA, Women empowerment, Economic Impact, SHG, Development

Special project for Sustainable Business Development of Innovative Coconut Based Micro-Enterprises for Holistic Growth and Poverty Alleviation (SUBICSHA), India's first women self employment enterprise was established in the year 2003 at Kozhikode. It is an innovative coconut based value added products venture, developed jointly by Perambra block panchayath and Indian Institute of Management, Kozhikode with the basic intention of promoting women empowerment with financial assistance of SGSY scheme. In this context, a study on "Economic impact of SUBICSHA on SHG members of Kozhikode district" was undertaken.

Gopal et al. (2009) ${ }^{[3]}$ stated that for improving the socio-economic status of their family, women folks engaged in agencies such as SUBICSHA, kudumbasree and other self help group projects have resulted in rural development as well as poverty alleviation.

Baskar and Sundar (2012 $)^{[1]}$ conducted an analytical study on the economic impact of self help groups in Kanchipuram district of Tamil Nadu. The study analyzed the economic impact of SHGs on its members during the pre and post-membership period by taking the variables such as income, expenditure, savings, borrowings, and asset creation. Statistical tools such as percentage and paired t-test were used. The outcome of the study strongly revealed that women have become confident about their future and have attained a considerable level of self-reliance and thereby increased economic conditions after joining the SHGs. Self-help group facilitated the members a healthier position in the society.

Bonny et al. (2014) ${ }^{[2]}$ studied URAVU in Wayanad and SUBICSHA in Kozhikode as self-employment models. Scaling up of enterprise activities to achieve economies of scale and ensure market and employment opportunity for marginalized women could also be ensured in these models. The results proved value creation as an appropriate quantitative parameter for the evaluation of SHGs and group 
enterprises in social sector. The results revealed the tremendous potential of PPP in entrepreneurship development in women SHGs and the need for promoting it as a major policy instrument. PPP also strengthened the systems of cooperation, collaboration and networking in women SHGs.

Ponnusamy et al. (2014) ${ }^{[5]}$ studied the role of SUBICSHA (public private- partnership (PPP)) model for agriculture and women empowerment in Kozhikode district and analyzed their strengths and weaknesses. The study concluded that PPPs have resulted to gender mainstreaming, food security, additional income and employment generation, poverty reduction, economic growth and agricultural production in rural areas.

Gupta and Singh (2012) ${ }^{[4]}$ conducted an analytical study on economic security among rural women through self help groups in Rajasthan. The data was analyzed by means of percentage, averages, standard deviation and chi-square tests. The study concluded that micro-finance programmes enabled women to contribute to the household economy, increased their intra household bargaining power. Thus micro financing through self help groups has transferred the real economic power in the hands of women and has considerably reduced their dependence on men. The chi square value of 7.58 showed the unavoidable role of SHGs in providing recognition to the women in the study area.

Saravanan $(2016)^{[6]}$ studied the impact of SHGs on the rural households through secondary sources in Tamil Nadu. The SHGs had a greater impact on both economic and social aspects of the beneficiaries. There was an evidence for increased household income, standard of living and food security. Microfinance had a significant role in poverty alleviation and rural development.

\section{DATA BASE AND METHODOLOGY}

\section{Sources of data}

The study was conducted in Kozhikode district using primary data. Kozhikode district was purposively selected because SUBICSHA was implemented in this district. Primary data for the study was collected from SHG members associated with SUBICSHA.

\section{Primary data}

For the collection of primary data SHGs associated with SUBICSHA were classified into high income generating SHGs (Group I) (income generated by Group I SHGs was more than ₹ 4 lakhs per annum), middle income generating SHGs (Group II) (income generated by Group II SHGs was in the range of ₹ 2 - 4 lakhs per annum), and low income generating SHGs (Group III) ( income generated by Group III SHGs was less than ₹ 2 lakhs per annum) based on the project report of SUBICSHA in 2011. Twenty SHGs each from the above three classes were selected at random, which make up the total number of SHGs selected to sixty. From each SHG, two members were selected at random to study the impact of SUBICSHA on SHGs, so that the total sample size was 120 SHG members. Income and expenditure details of selected SHG members before joining SUBICSHA pertain to the year 2003 and the information was calculated at current market price, while those after joining SUBICSHA pertain to the year 2017.

\section{Variables and their measurement}

Economic independence is the back bone of women empowerment and income generation is the tool for that. Income generated by members of self help group associated with SUBICSHA, other SHG activities and other off-farm and on farm income of the SHG members were collected both for pre and post joining periods in SUBICSHA. Details of household saving pattern and size were also collected

The household expenditure of the SHG members before and after joining the SUBICSHA was collected. Household expenditure pattern of SHG members on food, clothing, medical, education, recreation, transport and other expenses were collected

Comparison was made by analyzing the loan amount borrowed by the SHG members in pre and post SUBICSHA periods. The size of borrowing and institutional pattern of borrowing was also studied.

\section{Analytical framework}

Tools used for analysis were percentages, averages and paired t-test, percentages and averages were used to compute the economic variables such as 
income, expenditure, saving pattern, and borrowings of the SHG members in both pre SUBICSHA period and post SUBICSHA periods.

Paired t-test is used to assess whether there is any significant difference in income generation, expenditure pattern, size of savings, size of borrowings and asset creation of the SHG members in pre and post SUBICSHA periods.

\section{RESULTS AND DISCUSSION}

\section{Impact on aggregate income of SHG members}

Income has been taken as one of the most important indicators for assessing the economic impact of SHG on its members (Vinayagamoorthy and Pithadia, 2007) ${ }^{[7]}$. The aggregate average annual income of the respondents during the pre joining and post joining period has been shown in the table 1.

The study showed that, about 58 per cent of the total respondents were in the annual income level of less than ₹ 50,000 during the pre joining period while none of them were observed in this level during post joining period. Another interesting observation was that, all the respondents were in the annual income class of less than ₹ 1 lakh during pre joining period while only 2.5 per cent of the respondents were observed in this level during post joining period.
It can be seen that 70, 62.50 and 40 per cent of the Group I, II and III members respectively belonged to lowest income strata of less than ₹ 50,000 per annum in pre joining period. After joining SUBICSHA, the economic status of the respondent improved in a significant manner.

Percentage increase in average annual income over the period of Group I, Group II and Group III members were 330, 273, 167 per cent, respectively. It clearly proved the significant increase in income over a period of time. Among the respondents, Group I members had the highest average annual income of ₹ 1,99,625 in post SUBICSHA period.

Impact of SUBICHA on SHG members was statistically tested with paired t test and presented in table 2. It is evident from the result that, t-test value of 43.65 is significant at one percent level of significance. It implies that the income levels of SHG members has significantly improved after joining SUBICSHA.

\section{Impact on household expenditure}

A perusal of table 3 showed that expenditure pattern of respondents was found to differ significantly in pre and post joining periods. Consistent change in the expenditure over food, clothing, transportation, recreation and medical care was observed during the

Table 1: Distribution of respondents based on aggregate average annual income in pre and post-joining periods

\begin{tabular}{|c|c|c|c|c|c|c|c|c|c|}
\hline & \multirow{2}{*}{ Particulars } & \multicolumn{4}{|c|}{ Before joining SUBICSHA } & \multicolumn{4}{|c|}{ After joining SUBICSHA } \\
\hline & & Group I & Group II & Group III & Total & Group I & Group II & Group III & Total \\
\hline \multirow{7}{*}{ 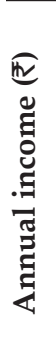 } & $\leq 50,000$ & $28(70.00)$ & $25(62.50)$ & $16(40.00)$ & $69(57.50)$ & $0(0.00)$ & $0(0.00)$ & $0(0.00)$ & $0(0.00)$ \\
\hline & $50,001-1,00,000$ & $12(30.00)$ & $15(37.50)$ & $24(60.00)$ & $51(42.50)$ & $0(0.00)$ & $0(0.00)$ & $1(2.50)$ & $1(0.83)$ \\
\hline & $1,00,001-2,00,000$ & $0(0.00)$ & $0(0.00)$ & $0(0.00)$ & $0(0.00)$ & $19(47.50)$ & $35(87.50)$ & $39(97.50)$ & $93(77.50)$ \\
\hline & $\geq 2,00,001$ & $0(0.00)$ & $0(0.00)$ & $0(0.00)$ & $0(0.00)$ & $21(52.50)$ & $5(12.50)$ & $0(0.00)$ & $26(21.66)$ \\
\hline & Total & $40(100)$ & $40(100)$ & $40(100)$ & $120(100)$ & $40(100)$ & $40(100)$ & $40(100)$ & $120(100)$ \\
\hline & Average & 46,349 & 49,225 & 53,650 & 49,741 & $1,99,625$ & $1,83,850$ & $1,43,700$ & $1,75,725$ \\
\hline & \multicolumn{5}{|c|}{ Percentage increase over the period } & 330.70 & 273.48 & 167.84 & 253.27 \\
\hline
\end{tabular}

Note: Figures in parentheses indicate percentage to total.

Table 2: Result of paired $t$ test for finding the difference between incomes earned before and after joining SUBICSHA

\begin{tabular}{ccccc}
\hline Particular & Mean & Standard deviation & t value & P value \\
\hline Before joining SUBICSHA & 49,741 & 12,905 & 43.65 & $1.34 \times 10^{-34 * * *}$ \\
After joining SUBICSHA & $1,75,725$ & 30,051 & \\
\hline
\end{tabular}

*** Significant at 1 per cent level of significance. 
Table 3: Distribution of respondents based on total annual expenditure in pre and post joining periods

\begin{tabular}{|c|c|c|c|c|c|c|c|c|c|}
\hline & \multirow[t]{2}{*}{ Particulars } & \multicolumn{4}{|c|}{ Before joining SUBICSHA } & \multicolumn{4}{|c|}{ After joining SUBICSHA } \\
\hline & & Group I & Group II & Group III & Total & Group I & Group II & Group III & Total \\
\hline \multirow{7}{*}{ 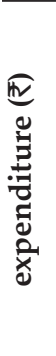 } & $0-42,550$ & $14(35)$ & $18(45)$ & $27(67.5)$ & $59(49.16)$ & $0(0)$ & $0(0)$ & $1(2.5)$ & $1(0.83)$ \\
\hline & $42,551-52,100$ & 19 (47.5) & $21(52.5)$ & $11(27.5)$ & $51(42.5)$ & $0(0)$ & $0(0)$ & $9(22.5)$ & $9(7.5)$ \\
\hline & $52,101-75,600$ & $7(17.5)$ & $1(2.5)$ & $2(5)$ & $10(8.3)$ & $13(32.5)$ & $8(20)$ & $30(75)$ & $51(42.5)$ \\
\hline & $75,601-1,24,800$ & $0(0)$ & $0(0)$ & $0(0)$ & $0(0)$ & $27(67.5)$ & $32(80)$ & $0(0)$ & $59(49.16)$ \\
\hline & Total & $40(100)$ & $40(100)$ & $40(100)$ & $120(100)$ & $40(100)$ & $40(100)$ & $40(100)$ & $120(100)$ \\
\hline & Average & 44,610 & 43,232 & 40,695 & 42,845 & 81,270 & 84,940 & 56,574 & 74,261 \\
\hline & \multicolumn{5}{|c|}{ Percentage increase over the period } & 82.18 & 96.47 & 39.02 & 73.32 \\
\hline
\end{tabular}

Note: Figures in parentheses indicate percentage to total.

Table 4: Result of paired $t$ test for finding the difference between incomes earned before and after joining SUBICSHA

\begin{tabular}{ccccc}
\hline Particulars & Mean & Standard deviation & t value & P value \\
\hline Before joining SUBICSHA & $42,845.66$ & $6,170.58$ & 21.84 & $6 \times 10^{-3 * * *}$ \\
After joining SUBICSHA & $74,261.37$ & $17,005.87$ & & \\
\hline
\end{tabular}

*** Significant at 1 per cent level of significance.

pre and post membership periods. There was not much difference in the average annual expenditure within the three groups in pre SUBICSHA period. Expenditure of Group I, II and III were ₹ 44,610, 43,232 and 40,695 respectively before joining SUBICSHA. But while comparing before joining SUBICSHA period with after joining SUBICSHA period, a notable difference was seen in the average expenditure, which almost doubled in the later period. A significant change was also noticed in each expenditure class also. In the post SUBICSHA period, 49.16 per cent of the total respondents were covered in the annual total expenditure strata of ₹ 75,601-1,24,800 and also 99.17 per cent of the total respondents have spent an amount greater than ₹ 42,551 annually. Members of Group II had the highest total expenditure of ₹ 84,940 per annum in post SUBICSHA period.

\section{Impact on cumulative savings}

The distribution of respondents based on cumulative savings for the past 15 years were presented in table 5. The table explains the increased savings of the respondents after joining SUBICSHA (99 per cent respondents did not have individual savings in pre SUBICSHA period). The total sample had an average savings of ₹ 37,375 and Group I, II and III had group average savings of ₹ 51,487, 34,462 and 26,175 respectively. Out of 120 respondents 48.32 per cent members saved an amount more than ₹ 34,250 over the years. Respondents started individual savings in financial institutions in the form of kuris, chits etc., only after joining SUBICSHA. From the data it was clearly evident that 47.5 per cent of the Group I (high income generating SHGs), 12.5 per cent of Group II (middle income generating SHGs) and 5 per cent of Group III (low income generating SHGs) members were able to save an amount greater than $₹ 54,250$ over the past one and a half decade. This savings pattern undoubtedly revealed the positive impact of SUBICSHA over SHG members. The saving habit and size of the savings of SHG members after joining SUBICSHA implies the magnificent impact of SUBICSHA on SHG members.

\section{Impact on cumulative borrowing}

The distribution of respondents based on aggregate borrowing was presented in table 6 . The table shows the elevated borrowing power of SHG members after joining SUBICSHA (99 per cent of SHG members started individual borrowing only after joining SUBICSHA). The SHG members were getting an assured income from SUBICSHA, this criteria made them eligible for credit from nationalized banks and other financial institutions. Financial institutions were interested to provide loans to individual, who have permanent and 
Table 5: Distribution of respondents based on cumulative savings for 15 years

\begin{tabular}{|c|c|c|c|c|c|c|c|}
\hline \multirow{2}{*}{\multicolumn{2}{|c|}{ Particulars }} & \multicolumn{4}{|c|}{ Cumulative savings $(₹)$} & \multirow{2}{*}{ Total } & \multirow{2}{*}{$\begin{array}{l}\text { Average savings } \\
\text { (₹) }\end{array}$} \\
\hline & & $0-30,000$ & $30,001-34,250$ & $34,251-54,250$ & $54,251-1,15,000$ & & \\
\hline \multirow{4}{*}{ 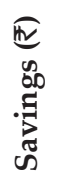 } & Group I & $7(17.50)$ & $1(2.50)$ & $13(32.50)$ & $19(47.50)$ & $40(100)$ & 51,487 \\
\hline & Group II & $19(47.50)$ & $5(12.50)$ & $11(27.50)$ & $5(12.50)$ & $40(100)$ & 34,462 \\
\hline & Group III & $28(70.00)$ & $2(5.00)$ & $8(20.00)$ & $2(5.00)$ & $40(100)$ & 26,175 \\
\hline & Total & $54(45.00)$ & $8(6.60)$ & $32(26.66)$ & $26(21.66)$ & $120(100)$ & 37,375 \\
\hline
\end{tabular}

Note: Figures in parentheses indicate percentage to total.

Table 6: Distribution of respondents based on cumulative borrowings

\begin{tabular}{|c|c|c|c|c|c|c|}
\hline \multirow{2}{*}{ Particulars } & \multicolumn{4}{|c|}{ Cumulative borrowing (₹) } & \multirow{2}{*}{ Total } & \multirow{2}{*}{$\begin{array}{c}\text { Average } \\
\text { borrowings (₹ }\end{array}$} \\
\hline & $0-20,000$ & $20,001-65,000$ & $65,001-1,20,000$ & $1,20,001-4,00,000$ & & \\
\hline Group I & $4(10.00)$ & $7(17.50)$ & $14(35.00)$ & $15(37.50)$ & $40(100)$ & $1,16,500$ \\
\hline Group II & $4(10.00)$ & $19(47.50)$ & $10(25.00)$ & $7(17.50)$ & 40 (100) & 78,362 \\
\hline Group III & $25(62.50)$ & $5(12.50)$ & $3(7.50)$ & $7(17.50)$ & $40(100)$ & 68,923 \\
\hline Total & $33(27.50)$ & $31(25.83)$ & $27(22.50)$ & $29(24.16)$ & $120(100)$ & 87,354 \\
\hline
\end{tabular}

Note: Figures in parentheses indicate percentage to total.

secured income. SUBICSHA made SHG members to satisfy these criteria.

The average borrowing pattern of Group I, II and III were characterized with ₹ $1,16,500$, ₹ $78,362.5$ and ₹ 68,923 respectively. The table showed that 17.5 per cent of Group II and III members and 37.5 per cent of Group I members had borrowed an amount greater than ₹ 1,20,000. Membership in SUBICSHA placed them in an income earning class, increased the trust worthiness in the society and increased the repayment capacity of loans.

These criteria made the respondents easier to avail as well as repay the loans. 99 per cent members started individual borrowing from financial institutions only after joining SUBICSHA. In addition to the institutional loans these SHG members were eligible and availed SHG member loans and other financial support such as grant for purchasing sewing machine and loan for investing in agricultural activities, from government also.

\section{CONCLUSION}

Economic impact of SUBICSHA on SHG members was analysed based on before and after joining status using percentage analysis and paired t-test. It revealed that the average annual income of SHG members was ₹ 49,741 in pre SUBICSHA period, whereas in post SUBICSHA period it reached up to ₹ $1,75,725$. Similarly total annual expenditure of SHG members was ₹ 42,845 in pre SUBICSHA period, whereas in post SUBICSHA period was ₹ 74,261. Most of the SHG members started individual savings as well as borrowings only after joining SUBICSHA. They had a cumulative average saving of $₹ 37,375$ and cumulative average borrowing of ₹ 87,354. Summing up, It was evident that the income levels, overall expenditure pattern, saving habit and borrowing power of SHG members have significantly improved after joining SUBICSHA. SUBICSHA as a women empowerment and poverty alleviation programme was successfully implemented in Kozhikode district of Kerala and SUBICSHA had significant economic impact on SHG members associated with it. Hence such initiatives may be replicated and promoted in other states of India.

\section{REFERENCES}

1. Baskar, D. and Sundar, K. 2012. An analytical study on economic impact of self-help group members in Kanchipuram district. IJMT., 2(9): 276-296.

2. Bonny, B.P., Prema, A. and Rajendran, P. 2014. Public private partnership models for women entrepreneurship in agriculture. Glob. J. Inc., 14(4): 34-42.

3. Gopal, M., Gupta, A. and Thomas, G.V. 2009. Importance of producing nucleus earthworm culture for the dissemination and popularization of coconut leaf vermicomposting technology. Cent. Plant. Crops. Res. Inst., 4(7): 134-139.

4. Gupta, S.S. and Singh, S.K. 2012. Economic security among rural women through Self-Help Groups: An analytical study. Indian. J. Ext. Educ., 12(2): 117-122. 
5. Ponnusamy, K., Manju, D.D., Bonny, B.P. and Sabitha, M. 2014. PPP and gender main streaming in agricultureLessons from field studies. Agric. Econ. Res. Rev., 27(4): 147-155.

6. Saravanan, M. 2016. Impact of self help groups on the socio economic development of rural household women in Tamil Nadu- A study. Int. J. Res., 4(7): 22-31.
7. Vinayagamoorthy. A. and Pathadia, V. 2007. Women empowerment through cooperative societies. Indian J. of Mark., 37(2): 30-33. 